\title{
Productive performance and parasitological control of kids supplemented with umbu fruits (Spondias tuberosa Arruda)
}

\author{
Desempenho produtivo e controle parasitologico de caprinos suplementados com frutos \\ de umbu ("Spondias tuberosa" Arruda)
}

\author{
NASCIMENTO, Thiago Vinicius Costa $^{1 *}$; NOGUEIRA, Daniel Maia ${ }^{2}$; \\ CAVALCANTE, Nilton de Brito ${ }^{2}$
}

\author{
${ }^{1}$ Universidade Federal da Bahia, Escola de Medicina Veterinária e Zootecnia, Programa de Pós- \\ Graduação em Ciência Animal, Salvador, Bahia, Brasil. \\ ${ }^{2}$ Embrapa Semiárido, Petrolina, Pernambuco, Brasil. \\ *Endereço para correspondência: thiagoven vet@hotmail.com
}

\section{SUMMARY}

Native fruits from Caatinga vegetation can be an important alternative to improve the productive performance of kids in the semi-arid region of Brazil. This work aimed to evaluate the effect of supplementation with Umbuzeiro fruits in natura over the weight gain and anthelmintic control of kids kept in Buffel grass pasture in the semi-arid zone of Pernambuco, Brazil. Twenty-four castrated, crossbreed kids were allocated into three treatments: 1) Control $(\mathrm{n}=8)$ fed exclusively with Buffel grass; 2) Umbu $1 \times$ ( $\mathrm{n}=$ 8) fed with fruits once a week and 3) Umbu $3 \times$ (n $=8$ ) fed with fruits for three times a week. The following parameters were evaluated: variation of body weight, faecal egg counts (FEC) and coproculture. Overall, the average consumption of Umbu fruits in natura was $1.48 \mathrm{~kg} / \mathrm{animal} /$ day, which corresponded to $133.5 \mathrm{~g}$ daily dry matter intake (DMI/animal/day). There were no significant difference $(\mathrm{P}>0.05)$ for any parameters evaluated. During the experimental period, the overall daily weight gain was variable between 108.75 to $116.70 \mathrm{~g} / \mathrm{animal} /$ day and the average FEC was 436 eggs. In the present study, the goat kids supplemented with fresh umbu fruits showed a good productive performance, however the supplementation with umbu did not control the infestation of gastrointestinal nematodes in kids.

Keywords: Buffel Grass, caatinga, weight gain

\section{RESUMO}

Os frutos nativos de plantas da Caatinga podem ser uma alternativa importante para proporcionar melhoria nos desempenhos produtivos dos caprinos na região semiárida brasileira. Objetivou-se com esse trabalho avaliar o efeito da suplementação com frutos do umbuzeiro in natura sobre o ganho de peso e o controle antihelmíntico em caprinos mantidos em pastagem de capim-buffel na região semiárida de Pernambuco. Foram utilizados 24 cabritos castrados e mestiços, os quais foram distribuídos homogeneamente em três tratamentos: 1) Controle, alimentaram-se exclusivamente de capim-buffel $(\mathrm{n}=8)$; 2), Frutos de umbu 1x por semana $(n=8)$, e 3$)$, Frutos de umbu $3 x$ por semana $(n=8)$. Foram realizadas as avaliações do peso corporal, contagem do número de ovos por grama de fezes (OPG) e coprocultura. O consumo médio do umbu in natura foi de 1,48 $\mathrm{kg} / \mathrm{animal} /$ dia, que correspondeu a média de 133,5 g de MS/animal/dia. A suplementação com umbu não afetou $(\mathrm{P}>0,05)$ nenhum dos parâmetros avaliados. $\mathrm{O}$ ganho de peso médio diário variou entre 108,75 e 116,70 g/animal/dia e o valor médio de OPG foi de 436 ovos. Neste estudo, os cabritos suplementados com frutos de umbu apresentaram bom desempenho produtivo, entretanto, a suplementação com umbu não controlou a infestação de nematódeos gastrintestinais.

Palavras-chave: capim-buffel, caatinga, ganho de peso 


\section{INTRODUCTION}

Supplementation with by-products from the agro-industry (AJILA et al., 2012) or native fruits from the Caatinga biome may be an important alternative to improve animal's performance (NUNES et al., 2015).

The umbu tree (Spondias tuberosa Arruda) is a native species of the Brazilian semi-arid region that can live over a hundred years withstanding the most severe water shortage conditions. Known as the "sacred tree of the drought", the umbu tree is important to the population of the semi-arid region for providing both water, which is stored in its roots, and fruit for human and animal consumption. The umbu tree has its harvesting season from December to April. It's a four-month period during which on average 30,000 units of fruit that weigh approximately $14 \mathrm{~g}$ each are produced, amounting to an average $350 \mathrm{~kg}$ of umbu fruit (BORGES et al., 2007).

In many cities of the Brazilian Northeast, farmers use the umbu fruit to produce pastries, juices, marmalade, liqueur, syrup, and jam (MAMEDE et al., 2013). However, a considerable portion of the produced fruits is not collected or used, and thus end up discarded. These fruits unused by producers or rejected by the industry is well-accepted by animals and can become a supplementary alternative for animals, especially as source of energy, since umbu is rich in it, with a high content of soluble carbohydrates and degrees Brix varying from 8.4 to 13.4 (ARAÚJO et al., 2011).

In addition, umbu is also rich in citric acid and phenolic compounds such as tannin, which contributes to the control of gastrointestinal nematodes. The tannin levels in umbu fruit are varied, e.g., Moreira et al. (2012) reported 42 to $48 \mathrm{mg} / 100 \mathrm{~g}$ of fruit pulp, while Costa et al. (2004) mentioned values of up to $126.27 \mathrm{mg} / 100 \mathrm{~g}$ pulp. According to Martínez-Ortíz-de-Montellano et al. (2013), the tannins may have an anthelmintic activity by decreasing the parasitic load or by reducing the fertility of nematode females, or even as a protection to the rumen degradability of the dietary protein, allowing it to be absorbed in the intestine.

The literature lacks data evaluating the effect of umbu fruit on the productive performance and possible anthelmintic effect in kids. The objective of this study was to evaluate weight gain and degree of gastrointestinal nematode infestation in kids fed umbu fruit, reared on a pasture of buffelgrass (Cenchrus Ciliaris L.) cv. Biloela during the rainy season in the semi-arid region of Northeast of Brazil.

\section{MATERIAL AND METHODS}

The study was conducted on the Experimental Field of Embrapa Semiarid, located in Petrolina-PE, Brazil. A total of 24 crossbred castrated kids at approximately nine months of age and with an initial body weight of $17.2 \mathrm{~kg}$ were used. Kids were distributed into three treatments with eight animals, such that homogeneous groups concerning age, weight, and average number of eggs per gram of feces (EPG) were obtained. The following treatments were carried out: 1) Control $(\mathrm{n}=8)$ : kids were kept exclusively on a buffelgrass pasture; 2) Umbu 1x $(\mathrm{n}=8)$ kids were fed the fruit once weekly; and 3) Umbu $3 x(n=8)$ kids were fed the fruit three times per week.

During daytime (08h00 to $17 \mathrm{~h} 00)$, all animals were kept on a buffelgrass 
pasture and then they were confined in a beaten-earth housed pens until $08 \mathrm{~h} 00$ of the following day. On the days that umbu was supplied, all animals were separated in housed pens with natural light, from $14 \mathrm{~h} 00$ to $08 \mathrm{~h} 00$ of the following day, and only the animals that were to consume the fruit (treatments Umbu 1x and Umbu 3x) received the fruit. In this days, the control animals had only access to water, the similar methodology was given to Umbu $1 \mathrm{x}$ group when they didn't received.

The ripe fruit was collected from the floor, below the umbu trees, and supplied as it is (fresh), ad libitum. The authors observed that the intake of umbu was around of $15.0 \mathrm{~kg} /$ day/group in the group that ate the fruits. This amount was enough to be an ad libitum offer because every day after feeding, the residual was collected into the trough. To determine the total intake of the fruit, the total amount supplied and leftovers were quantified in the next day.

Samples of umbu fruit and Buffel grass were analyzed according to AOAC (1990) of dry matter (DM; $\left.n^{\circ} 934.01\right)$; Ash ( $\left.{ }^{\circ} 930.05\right)$; crude protein by Kjeldahl method $\left(\mathrm{n}^{\circ} 981.10\right)$, and neutral and acid detergents fiber by Van Soest et al. (1991).

The chemical analyses of the Buffel grass and umbu fruits consumed without the seeds is showed in Table 1.

Table 1. Chemical composition of the Buffelgrass and Umbu fruit without the seed

\begin{tabular}{lcc}
\hline Chemical composition & Buffel grass & $\begin{array}{c}\text { Umbu fruit } \\
\text { (Pulp + Umbu peel) }\end{array}$ \\
\hline DM\% $\%$ & 27.9 & 8.8 \\
CP\% & 11.0 & 0.6 \\
NDF\% & 70.2 & 59.3 \\
ADF\% & 40.3 & 43.6 \\
ASH\% & 9.1 & 14.0 \\
IVDMD\% & 51.8 & 78.9 \\
\hline
\end{tabular}

Every 14 days, in the early morning, the animals were weighed after having been feed-deprived for $12 \mathrm{~h}$. Four observations were made over 56 days of experimental period. Based on these body weights, the total weight gain (TWG) and the average daily weight gain (DWG) of the animals were determined. The TWG was calculated as the difference between the body weights at the end and beginning of the experiment; DWG was obtained by dividing the TWG by the number of experimental days. On the same day of weighting, fecal samples were collected for the count of eggs per gram (EPG), according a technique modified by
Ueno \& Gonçalves (1998). Stool culture was also performed to identify the genre of the infective larvae (L3) according to the technique described by Gordon \& Whitlock (1939).

The intake of fruit pulp by the animals was estimated by subtracting the weight of the seed, which corresponds to $10 \%$ of the fruit weight, from the total intake (RESENDE et al., 2004), since animals ingest the fruit and regurgitate the seeds during rumination.

The total dry matter intake $\left(\mathrm{DMI}_{\mathrm{TOTAL}}\right)$ was estimated by total feces collection, which was performed using bags and harnesses attached to the animals. Prior to commencement of the study, kids 
were adapted to the bags attached to the animals for three days. The quietest animals were selected to use the bags and collect the feces. Total feces collections occurred during $24 \mathrm{~h}$, during two days, at two times: from day 26 to 28 , and from 54 to 56 of the experimental period. The bags' content was removed to plastic bag and weighed (fresh stools), sampled at $20 \%$, dried in a ventilated oven at $55^{\circ} \mathrm{C}$, and weighed again to check the fecal dry matter content and total fecal production $\left(\mathrm{FP}_{\text {TOTAL }}\right)$.

For the total fecal collection, three kids per treatment were used - always the same animals in the sub-periods. The total DMI by the animals kept exclusively on buffelgrass pasture was estimated through following equation: $\mathrm{DMI}_{\mathrm{GRASS}}$ $\left(\mathrm{kg} \mathrm{DM}\right.$ animal ${ }^{-1} \times$ day $\left.^{-1}\right)=\mathrm{FP}_{\text {TOTAL }} / 1-$ IVDMD of the grass, where: IVDMD = in vitro dry matter digestibility. The total DMI by the animals that received the umbu fruit was estimated by summing $\mathrm{DMI}_{\text {GRASS }}$ and DMI $\mathrm{DMBU}_{\text {UMU }}$. The DMI $\mathrm{DIRASS}_{\text {GR }}$ was estimated using the following equations: DMI $_{\text {GRASS }}=\left(\mathrm{FP}_{\text {GRASS }} / 1-\right.$ IVDMD $\left._{\text {GRASS }}\right) ; \mathrm{FP}_{\text {GRASS }}=\left(\mathrm{FP}_{\text {TOTAL }}-\right.$ $\mathrm{FP}_{\mathrm{UMBU}}$ ); and $\mathrm{FP}_{\mathrm{UMBU}}=\mathrm{DMI}_{\mathrm{UMBU}}-$ $\left(\mathrm{DMI}_{\mathrm{UMBU}} \times\right.$ IVDMD $\left._{\text {UMBU }}\right)$ (VOLTOLINI et al., 2009).

The proportion of dry matter intake from umbu pulp and total dry matter relative to body weight (BW) was calculated as follows: $\% \quad \mathrm{DMI}_{\mathrm{UMBU}} / \mathrm{BW}=$ $\mathrm{DMI}_{\mathrm{UMBU}} /$ (initial weight of the group + final weight of the group/2) and \% $\mathrm{DMI}_{\text {TOTAL }} / \mathrm{BW}=\mathrm{DMI}_{\mathrm{TOTAL}} /$ (initial weight of the group + final weight of the group/2).

The experimental design was completely randomized, with three treatments and eight replicates per treatment. The EPG results were subjected to logarithmic transformation, using the equation Log $(x+1)$, where " $x$ " is the EPG result. The percentages of larvae from the stool culture between treatments were compared using the Chi-squared test. The variation in body weight and the EPG results after logarithmic transformation were subjected to analysis of variance (ANOVA) according to the procedures of the Statistical Analysis System - SAS (2011), and means were compared by Tukey's test, adopting 5\% probability. The age, initial body weight and EPG were considered as covariate when significant at $5 \%$ of probability $(\mathrm{P}<0.05)$.

\section{RESULTS AND DISCUSSION}

In this study, the $\mathrm{CP}$ contents was $11 \%$ DM (Table 1). This content of CP varies from $3 \%$ to $12 \%$ of $\mathrm{CP}$ throughout the year, and in the rainy season the $\mathrm{CP}$ contents are higher, reaching $12 \%$ at the young stage before the flowering in that period (MONÇÃO et al., 2011). Regarding to the IVDMD of the buffelgrass was $51.8 \%$, which was within the range reported by Formiga et al. (2011), who observed that the values of IVDMD in buffelgrass varied from 42.2 to $53.1 \%$.

The percentage of CP found in the umbu fruit was $0.6 \%$ (Table 1 ). The content of $\mathrm{CP}$ varies from 0.31 to $0.75 \%$ because of its variety (DE PAULA et al., 2012). In the present study, our findings were similar to the data reported by Santos et al. (2010). The in vitro digestibility (IVDMD) of umbu was similar to the values of some concentrate feeds (Table1) such as wheat bran, with $72 \%$ to 77\% (LOPES et al., 2010).

Supplementation with umbu fruit did not influence $(\mathrm{P}>0.05)$ the intake of forage dry matter or the total feed intake (Table 2). Although the umbu fruit showed good acceptance by the animals, a low average intake of fresh umbu was recorded. 
Rev. Bras. Saúde Prod. Anim., Salvador, v.17, n.3, p.520-528 jul./set., $2016 \quad$ http://www.rbspa.ufba.br ISSN 15199940

Table 2. Intake levels of in natura and dry matter of umbu (DMI Umbu), dry matter of buffelgrass (DMI Buffel), total dry matter intake (DMIt), percentages of average intake of dry matter of umbu in relation to body weight (\% DMI $\mathrm{Umbu} / \mathrm{BW}$ ) and percentages of average total dry matter intake in relation to body weight (\% DMI $\mathrm{t} / \mathrm{BW})$ of kids

\begin{tabular}{lccccc}
\hline Parameters & Control & Umbu 1x & Umbu 3x & CV & P value \\
\hline Intake of Umbu in natura & $0^{\mathrm{b}}$ & $310.9^{\mathrm{a}}$ & $303.0^{\mathrm{a}}$ & 16.1 & $<0.01$ \\
(g/100kgBW/day) & $0^{\mathrm{b}}$ & $135.1^{\mathrm{a}}$ & $132.0^{\mathrm{a}}$ & 16.1 & $<0.01$ \\
DMI Umbu (g/animal/day) & $0^{\mathrm{b}}$ & $0.65^{\mathrm{a}}$ & $0.64^{\mathrm{a}}$ & 11.8 & $<0.01$ \\
\% DMI Umbu/ BW & $547.0^{\mathrm{a}}$ & $409.7^{\mathrm{b}}$ & $436.0^{\mathrm{b}}$ & 6.8 & $<0.01$ \\
DMI Buffel (g/animal/day) & $2.7^{\mathrm{a}}$ & $2.0^{\mathrm{b}}$ & $2.0^{\mathrm{b}}$ & 4.7 & $<0.01$ \\
\% DMI Buffel/ BW & 547.0 & 544.8 & 568.1 & 6.2 & 0.82 \\
DMItotal(g/animal/day) & 2.7 & 2.6 & 2.7 & 4.2 & 0.44 \\
\% DMItotal/ BW & & &
\end{tabular}

Values with different letters $\left({ }^{\mathrm{a}, \mathrm{b}}\right)$ in the same row are significantly different between treatments $(\mathrm{P}<$ $0.05)$.

The results showed that the average intake of fresh umbu were lower than those found by Resende et al. (2004), who worked with adult goats and observed an average intake of fresh umbu slightly above $2.0 \mathrm{~kg} /$ animal/day. In the present study, the lower intake of fresh fruit may be explained by two factors: first, animals were young (9 months-old), and consequently had a low body weight; this fact is confirmed by the results for percentage of $\mathrm{DMI}_{\mathrm{UMBU}}$ relative to the kids' bodyweight, which are similar to the $0.6 \%$ found by Resende et al. (2004). Secondly, the authors speculate that the fruit acidity might have inhibited intake. According to Costa et al. (2004) and Bastos et al. (2016), the $\mathrm{pH}$ of umbu may vary according to the maturation stage and to the cultivar, with values ranging from 1.7 to 3.3. An option to increase $\mathrm{DMI}_{\mathrm{UMBU}}$ is supplying it in dry flour or powdered meal, which can be used as a feeding supplement during the dry season of the year.

The significant difference between the intake of DM buffel was probably due to a substitution effect, as the Control animals probably ingested less energy than other groups and tried to compensate intake with more grass than the other groups. Normally, adult goats need to intake a minimal level of energy per day (7.6 MJ ME/day) to grow and to accumulate fat reserves.

The percentages of the total DMI relative to the bodyweight (2.6 to $2.7 \%$ ) were in accordance with Dias et al. (2010), who reported that growing goats weighing $20.0 \mathrm{~kg}$ consume around $3.0 \%$ of their bodyweight in feed dry matter.

As can be observed in Table 2, Control group that was kept on the buffel grass exclusively consumed more dry matter of grass than the animals supplemented with umbu, but this fact did not alter their productive performance (Table 3 ), because of the total intake of dry matter that was similar. As a result, it can be assured that the nutritional requirements of the kids kept exclusively on buffelgrass pastures or fed umbu were met.

During 56 days of experimental evaluation, goat kids showed a weight gain over $6.0 \mathrm{~kg}$, but no significant difference $\quad(\mathrm{P}>0.05)$ were observed among treatments for the parameters of initial and final body weights or total weight gain (TWG) and daily weight gain (DWG) (Table 3 ). 
Rev. Bras. Saúde Prod. Anim., Salvador, v.17, n.3, p.520-528 jul./set., $2016 \quad$ http://www.rbspa.ufba.br

Table 3. Initial and final Body weight, total weight gain and mean daily weight gain of kids fed with umbu and kept in buffel-grass pasture

\begin{tabular}{lccccc}
\hline Parameters & Control & Umbu 1x & Umbu 3x & CV* & P value \\
\hline Initial body weight $(\mathrm{kg})$ & 16.7 & 17.6 & 17.6 & 0.19 & - \\
Final body weight $(\mathrm{kg})$ & 23.2 & 23.8 & 23.7 & 0.19 & 0.49 \\
Total weight gain (kg/56 days) & 6.5 & 6.2 & 6.1 & 24.40 & 0.85 \\
Daily weight gain (g/day) & 116.7 & 111.6 & 108.7 & 24.40 & 0.85 \\
\hline
\end{tabular}

No significant difference between treatments $(\mathrm{P}>0.05) . *$ Coefficient of Variation

The experimental groups showed similar performance $(\mathrm{P}>0.05)$. The DWG was on average over $108.7 \mathrm{~g} / \mathrm{animal} /$ day $(\mathrm{P}>0.05)$, considered a relevant for grazing goats. This result was higher than the $56.0 \mathrm{~g} /$ day found by Nogueira et al. (2012).

Oliveira \& Berchielli (2007) reported that the dietary tannin may inhibit dry matter intake; however, considering that the total DMI among the treatments was similar, it can be speculated that this inhibitory effect of tannin on the dry matter intake was not observed in the present study.

The results for EPG varied from 113 to 1,225 , although the mean was 436 eggs (Table 4). Ueno \& Gonçalves (1998) classified the parasitic infestation as mild-degree in the range of 500 to 800 eggs; moderate from 800 to 1,500 eggs; and elevated above 1,500 eggs.

Tabela 4. Mean number of eggs per gram (EPG) in kids fed with umbu fruits and kept in buffel-grass pasture

\begin{tabular}{lcccccc}
\hline EPG (days) & Control & Umbu 1x & Umbu 3x & Average & CV $^{*}$ & P value \\
\hline EPG(0) & 119 & 125 & 113 & 117 & 0.19 & 0.88 \\
EPG(14) & 191 & 250 & 150 & 177 & 0.19 & 0.49 \\
EPG(28) & 479 & 571 & 150 & 361 & 0.20 & 0.37 \\
EPG(42) & 373 & 450 & 437 & 396 & 0.20 & 0.50 \\
EPG(56) & 1,082 & 1,200 & 1,225 & 1,132 & 0.19 & 0.37 \\
\hline Average & 449 & 519 & 415 & 436 & --- & --- \\
\hline
\end{tabular}

No significant difference between treatments $(\mathrm{P}>0.05)$. $*$ Coefficient of Variation after to transformation in $\log (\mathrm{X}+1)$.

An increased number of EPG was observed in the last fecal sample (Table 4), which may be related to the beginning of the raining season, which probably favored the nematodes to complete their biological cycle. Thus, the authors speculate that the umbu fruits apparently did not have any influence on the control of the gastrointestinal nematodes. This fact might have resulted from the low amount of ingested tannin or from the type of tannin in the umbu fruit, since the majority of studies utilizing tannin to control nematodes adopt the condensed tannin present in leaves and stems (JUHNKE et al., 2012; MARTÍNEZORTÍZ-DE-MONTELLANO et al., 2013). Usually a plant rich in tannin affect the reproductive and mechanical characteristics of the nematode, and tannin act as reducer the parasitic load (MARTÍNEZ-ORTÍZ-DEMONTELLANO et al., 2013). Considering the tannin content of 
$126.3 \mathrm{mg} / 100 \mathrm{~g}$ DM of Umbu pulp (COSTA et al., 2004) and the intake of umbu pulp of 132 to $135 \mathrm{~g} \mathrm{DM} /$ day observed in the present work, it is estimated that the tannin intake varied from 166 to $170.4 \mathrm{mg} / 100 \mathrm{~g}$ pulp. Shalders et al. (2014) reported that the necessary amount of tannin for an effective antiparasitic activity was 20 to $30 \%$ of that ofBrazilian pepper cake (Schinus terebinthifolius Raddi), which corresponds to concentrate of
$498 \mathrm{mg} / 100 \mathrm{~g}$ pulp of tannin, approximately. Therefore, in the present study, the amount of tannin consumed by the animals was insufficient to provide an effective anthelmintic action.

The stool culture analyses demonstrate that 53.2 to $81.8 \%$ of the larvae were Haemonchus contortus, followed by low percentages of Trichostrongylus sp., Oesophagostomun sp., and Strongyloides papillosus (Table 5).

Table 5. Percentage of infective larvae found in coprocultures from kids fed with umbu fruits in semi-arid region

\begin{tabular}{lccc}
\hline Infective larvae & Control & Umbu 1x & Umbu 3x \\
\hline Haemonchus contortus (\%) & 68.1 & 53.2 & 81.8 \\
Trichostrongylus sp. (\%) & 13.1 & 19.1 & 15.9 \\
Oesophagostomun sp.(\%) & 18.8 & 23.4 & 2.3 \\
Strongyloides papillosus $(\%)$ & 0 & 4.3 & 0 \\
\hline
\end{tabular}

No significant difference between treatments $(\mathrm{P}>0.05)$.

The results of the present study corroborate the literature data, which describe that in the semi-arid region over $80 \%$ of the helminths in sheep and goat are caused by Haemonchus contortus (VILELA et al., 2012). Despite the greater prevalence of Haemonchus contortus, there was no reduction or loss in the animals' productive performance. Similarly, the supply of umbu fruit had no influence on the genre of the nematode L3 larvae.

This study represented the first attempt to describe the effects of supplementation with fresh umbu fruits on the productive performance and control of gastrointestinal nematodes in kids. The low dry matter intake of umbu fruits (135g/animal/day) can be explained by the high water content in the fruits and/or probably by the fruit acidity. An alternative to increase the dry matter intake of umbu is supplying it in dry flour meal. The goat kids supplemented with fresh umbu fruits showed a good productive performance, showing a daily weight gain greater than $108.7 \mathrm{~g} /$ animal $/$ day. The estimated intake of tannin in umbu fruits (166 to $170.4 \mathrm{mg} / 100 \mathrm{~g}$ ) was probably not enough to control the infestation of gastrointestinal nematodes in kids.

\section{REFERENCES}

ASSOCIATION OF ANALYTICAL CHEMISTS - AOAC. Official methods of analysis. 12. ed. Washington, D.C., 1990. 1094p.

AJILA, C.M.; BRAR, S.K.; VERMA, M.; TYAGI, D.R.; GODBOUT, S.; VALÉRO, J.R. Bio-processing of agrobyproducts to animal feed. Critical Review Biotechnology, v.32, n.4, p.382-400, 2012. 
Rev. Bras. Saúde Prod. Anim., Salvador, v.17, n.3, p.520-528 jul./set., $2016 \quad$ http://www.rbspa.ufba.br ISSN 15199940

ARAÚJO, D.L. de; SILVA, S.F. da; FREITAS, B.V. de; ARAÚJO D.L. de Caracterização física e Brix de spondias em diferentes estágios de maturação. Revista Verde, v.6, n.5, p.160-165, 2011.

BASTOS, J.S.; MARTINEZ, E.A.; DE SOUZA, S.M.A. Características físicoquímicas da polpa de umbu (Spondias tuberosa Arruda Camara) comercial: Efeito da concentração. Journal of Bioenergy and Food Science, v.3, n.1, p.11-16, 2016.

BORGES, S.V.; MAIA, M.C.A.; GOMES, R.C.M.; CAVALCANTI, N.B. Chemical composition of umbu (Spondias tuberosa Arr. Cam) seeds. Quimica Nova, v.30, p.49-52, 2007.

COSTA, N.P.; LUZ, T.L.B.; GONÇALVES, E.P.; BRUNO, R.L.A. Caracterização físico-química de frutos de umbuzeiro (Spondias tuberosa A. Camara.) colhidos em quatro estádios de maturação. Biosciencias Journal, v.20, p.65-71, 2004.

DE PAULA, B.; CARVALHO FILHO, C.D.; MATTA, V.M. da; MENEZES, J. da S.; LIMA, P. da C.; PINTO, C.O.; CONCEIÇÃO, L.E.M.G. Produção e caracterização físico-química de fermentado de umbu. Ciência Rural, v.42, n.9, p.1688-1693, 2012.

DIAS, A.M.A.; BATISTA, A.M.V.; CARVALHO, F.F.R.; GUIM, A.; SILVA, G.; SILVA, A.C. Consumo e digestibilidade dos nutrientes e desempenho de caprinos recebendo farelo grosso de trigo na dieta em substituição ao milho. Revista Brasileira de Zootecnia, v.39, p.831836, 2010.

FORMIGA, L.D.A. da S.; PEREIRA FILHO, J.M.; OLIVEIRA, N.S.; SILVA, A.M. de A.; CÉZAR, M.F.; SOARES, D. da C. Valor nutritivo da vegetação herbácea de caatinga enriquecida e pastejada por ovinos e caprino Revista Brasileira de Saúde e Produção Animal [online], v.12, n.2, p.403-415, 2011.

GORDON, H.M.; WHITLOCK, H.V . A new technique for counting nematode eggs in sheep faeces, Journal of the Council for Scientific and Industrial Research, v.12, p.50-52, 1939.

JUHNKE, J.; MILLER, J.; HALL, J.O.; PROVENZA, F.D.; VILLALBA, J.J. Preference for condensed tannins by sheep in response to challenge infection with Haemonchus contortus Veterinary Parasitology, v.188, p.104-114, 2012.

LOPES, F.C.F.; DORNELAS, R.A.C.; PORTUGAL, J.A.B.; CARNEIRO, J.C.; VERNEQUE, R.S.; SILVA e OLIVEIRA, J.; ARCURI, P.B.; DUQUE, A.C.A. Digestibilidade da matéria seca de silagens de milho e de suplementos concentrados determinada por procedimentos in vitro. Arquivo

Brasileiro de Medicina Veterinária e Zootecnia, v.62, p.1167-1173, 2010.

MAMEDE, M.E. de O.; CARVALHO, L.D. de; VIANA, E. de S.; OLIVEIRA, L. A. de; SOARES FILHO, W. dos S.; RITZINGER, R. Production of dietetic jam of Umbu-Caja (Spondias sp.): physical, physicochemical and sensorial evaluations Food and Nutrition

Sciences, v.4, p.461-468, 2013.

MARTÍNEZ-ORTÍZ-DEMONTELLANO, C.; ARROYO LÓPEZ, C.; FOURQUAUX, I.; TORRES-ACOSTA, J.E.J.; SANDOVAL-CASTRO, C.A.; HOSTE, H. Scanning electron microscopy of Haemonchus contortus exposed to tannin-rich plants under in vivo and in vitro conditions. Experimental Parasitology, v.33, p.281-286, 2013. 
Rev. Bras. Saúde Prod. Anim., Salvador, v.17, n.3, p.520-528 jul./set., 2016 http://www.rbspa.ufba.br ISSN 15199940 http://dx.doi.org/10.1590/S1519-99402016000300017

MONÇÃO, F.P.; OLIVEIRA, E.R. de; TONISSE, R.H. de; GOES, B. de O capim-buffel. Agrarian, v.4, n.13, p. 258264, 2011.

MOREIRA, A.C.C.G.; NASCIMENTO, J.D.M.; ANDRADE, R.A.M.S.; MACIEL, M.I.S.; MELO, E.de A. Fitoquímicos bioativos em frutos de genótipos de cajáumbuzeiras. Alimentos e Nutrição, v.23, n.2, p.235-241, 2012.

NOGUEIRA, D.M.; PARKER, A.; VOLTOLINI, T.V.; MORAES, S.A.; MOREIRA, J.N.; ARAÚJO, G.G.L.; FILHO, C.G. Reproductive and Productive Performance of Crossbred Goats Submitted to three Matings in two Years Under an Agro-Ecological Production System in the Semi-Arid Region of Brazil.

Journal of Animal Production

Advances, v.2, n.9, p.429-435, 2012.

NUNES, A.T.; LUCENA, R.F.P. de; SANTOS, M.V.F. dos;

ALBUQUERQUE, U.P. Local knowledge about fodder plants in the semi-arid region of Northeastern Brazil. Journal of Ethnobiology and Ethnomedicine, v.11, 12p., 2015.

OLIVEIRA, S.G.; BERCHIELLI, T.T. Potencialidades da utilização de taninos na conservação de forragens e nutrição de ruminantes - revisão. Archives of Veterinary Science, v.12, n.1, p.1-9, 2007.

RESENDE, G.M.; CAVALCANTI, N.B.; DRUMOND, M.A. Consumo de frutos do imbuzeiro (Spondias tuberosa Arruda) pelos caprinos na caatinga.

Agrossilvicultura, v.1, p.203-210, 2004.

SANTOS, M.B.; CARDOSO, R.L.; FONSECA, A.A.O.; CONCEIÇÃO, M.N. Caracterização e qualidade de frutos de umbu-cajá (spondias tuberosa $\mathrm{x} s$. mombin) provenientes do recôncavo sul da Bahia. Revista Brasileira de Fruticultura, v.32, p.1089-1097, 2010.
SAS. Statistical Analysis System: user's guide. Version 9.3. Cary, NC: Institute Inc., 2011.

SHALDERS, E.; ZANINI, S.F.; SOUSA, D.R. de; BARIONI, G.; CLIPES, R.C.; AVELAR, B.R.; SUHET, J.M.M.

Percentual de suplementação de fonte taninífera na ração concentrada de caprinos jovens sobre o desempenho e carga parasitária. Ciência Rural, v.44, n.6, p.1100-1105, 2014.

UENO, H.; GONÇALVES, P. C. Manual para diagnóstico de helmintoses de ruminantes. $4^{\mathrm{a}}$ ed. Tokyo, Japan International Cooperation Agency, 1998. $143 p$.

VAN SOEST, P.J.; ROBERTSON, J.B.; LEWIS, B.A. Methods for dietary, neutral detergent, and nonstarch polysaccharideas in relation to animal nutrition Journal of Dairy Science, v.74, n.10, p.3583-3597, 1991.

VILELA, V.L.R.; FEITOSA, T.F.; LINHARES, E.F.; ATHAYDE, A.C.R.; MOLENTO, M.B.; AZEVEDO, S.S. FAMACHA@ method as an auxiliary strategy in the control of gastrointestinal helminthiasis of dairy goats under semiarid conditions of Northeastern Brazil.

Veterinary Parasitology, v.190, p.28184, 2012.

VOLTOLINI, T.V.; MOREIRA, J.N.; NOGUEIRA, D.M.; PEREIRA, L.G.R.; AZEVEDO, S.R.B.; LINS, P.R.C. Fontes protéicas no suplemento concentrado de ovinos em pastejo. Acta Scientiarum. Animal Sciences, v.31, p.61-67, 2009.

Data de recebimento: 18/06/2015

Data de aprovação: 20/07/2016 